\title{
Speciation in the coral-boring bivalve Lithophaga purpurea: evidence from ecological, biochemical and SEM analysis
}

\author{
I. Brickner ${ }^{1,2}$, E. Kramarsky-Winter ${ }^{1}$, O. Mokady ${ }^{1}$, Y. Loya ${ }^{1, *}$ \\ ${ }^{1}$ Department of Zoology, The George S. Wise Faculty of Life Sciences, Tel Aviv University, Tel Aviv 69978, Israel \\ ${ }^{2}$ Department of Life Sciences, Bar Ilan University, Ramat Gan 52900, Israel
}

\begin{abstract}
The boring mytilid Lithophaga purpurea densely inhabits the scleractinian corals Cyphastrea chalcidicum (Forskal, 1775) and Montipora erythraea Marenzeler, 1907 in the Gulf of Eilat, Red Sea. Profound differences in reproductive seasons, postlarval shell morphology and isozyme polymorphism exist between the bivalve populations inhabiting the 2 coral species which share the same reef environments. Two distinct reproductive seasons were identified in the bivalves: L. purpurea inhabiting $M$. erythraea reproduce in summer, while those in C. chalcidicum reproduce in late fall or early winter. SEM observations revealed distinct postlarval shell morphologies of bivalves inhabiting the 2 coral hosts. Postlarvae from $C$. chalcidicum are characterized by tooth-like structures on their dissoconch, as opposed to the smooth dissoconch surface of postlarvae from $M$. erythraea. In addition, there is a significant difference $(p<0.001)$ in prodissoconch height between the 2 bivalve populations. Results obtained from isozyme electrophoresis showed distinct patterns of aminopeptidase (LAP) and esterase polymorphism, indicating genetic differences between the 2 populations. These data strongly support the hypothesis that $L$. purpurea inhabiting the 2 coral hosts are indeed 2 distinct species. Species specificity between corals and their symbionts may therefore be more predominant than previously believed
\end{abstract}

\section{INTRODUCTION}

A common definition of the term species is included in the 'biological species concept' as 'groups of actually or potentially interbreeding natural populations, which are reproductively isolated from other groups' (Mayr 1963). Speciation may, at times, be affected by physical boundaries (as in allopatric speciation) and/or reproductive boundaries (as in sympatric speciation). Thus, a new species may slowly evolve due to some physical or physiological boundaries which keep 2 or more groups from genetically mixing (Tauber \& Tauber 1989). In order to understand important ecological phenomena, such as species specific interactions between different organisms, systematic accuracy to the species level is imperative. In the present study, we examine 2 bivalve populations which are currently defined as 1 species, but are found within 2 different coral hosts.

\footnotetext{
- Addressee for correspondence
}

Boring organisms play an important role in regulating the growth of coral reefs (MacGeachy \& Stearn 1976). Bivalves belonging to the subfamily Lithophaginae (Mytilidae: Bivalvia) are responsible for the erosion and eventual destruction of a wide range of calcareous substrates (Morton 1983). Members of the genus Lithophaga bore in a variety of live coral hosts in the Gulf of Eilat, Red Sea (Loya 1981, Brickner 1985. Winter 1985). The common corals Montipora erythraea and Cyphastrea chalcidicum were found to be infested by purple colored bivalves identified by K. Kleemann as Lithophaga purpurea Kleemann. Lithophaginae are taxonomically categorized by various physical characteristics such as coloration, shell size and structure and soft body morphology (Wilson 1979, Kleemann 1980, Morton \& Scott 1980). Due to the strong resemblance between species of live-coral boring Lithophaga, morphological techniques alone provide a rather subjective method of taxonomy (see McLaughlin et al. 1982). L. purpurea is a good example of these taxonomic difficulties. Kleemann (1980) claims that Litho- 
phaga lima reported by Gohar \& Soliman (1963) boring in Montipora spp. and Cyphastrea spp. in the Red Sea is, in fact, L. purpurea. His definition of this species from the Great Barrier Reef is based on the morphology and texture of the valves (Kleemann 1980).

Coral host specificity of live-coral boring Lithophaga spp. ranges from single host borers to wide spectrum borers (Morton 1983). These bivalves are sessile throughout their adult life span. Fertilization occurs in the water column (Culliney 1971, Scott 1988). The planktonic larvae of Lithophaga spp. select a settlement substrate and metamorphose irreversibly on it (Scott 1988, Mokady et al. 1993). Thus, it is this stage in the bivalves' life history which is responsible for the observed host specificity (Mokady et al. 1991, 1992). Once settled and metamorphosed, the adult boring bivalve may be subjected to morphogenic effects of its habitat. For this reason, Goodsell et al. (1992) suggested that closer examination (SEM) of larvae and early postlarvae of lamellibranch species might provide a means of early identification and help resolve taxonomic ambiguities.

Recently, Morrow et al. (1992) used allozyme electrophoresis to distinguish between 2 populations of dorid nudibranchs of the genus Doto which feed on 2 different hydroid species in the same environment. The genetic divergence found by Morrow et al. (1992) in the nudibranch Doto coronata resulted in the definition of the 2 new species Doto sarsiae and Doto hydrallmaniae. We believe that in addition to morphology, other research tools, including SEM examination, ecological observations, and biochemical characteristics (i.e. protein electrophoresis; see Koehn \& Mitton 1972), may help resolve taxonomic ambiguities between bivalve populations inhabiting corals.

The corals Montipora erythraea and Cyphastrea chalcidicum belong to different families (Acroporidae and Faviidae respectively) and are different in growth form, surface topography and other features. These differences may act as a driving force for speciation of cryptobionts such as boring bivalves (see Wilson 1979).

In the current study we apply biochemical and SEM methods combined with ecological observations to try and resolve the taxonomic question of whether the Lithophaga purpurea populations found in Montipora erythraea and Cyphastrea chalcidicum are actually 1 species. This may shed a new light on our understanding of species distributions and species specific interactions within the coral reef.

\section{MATERIALS AND METHODS}

Monthly samples of the massive corals Cyphastrea chalcidicum and Montipora erythraea were collected during 1982-1983 from the reef at the H. Steinitz Marine Biology Laboratory in the Gulf of Eilat. Three to five Lithophaga purpurea-infested coral colonies of each species were collected at 3 to $6 \mathrm{~m}$ depth. The corals were broken apart using a hammer and chisel in order to release intact bivalves. The entire mussel population was extracted from each coral and measured for length, width and height (see Morton \& Scott 1980). Dimensions measured were used to construct allometric relationships.

The reproductive condition of the mussels was determined according to the reproductive index (RI) defined by Seed (1969). Smears of the bivalves' mantle were examined microscopically for the appearance of gonadal tissue. The gonadal index (GI) was determined using the method of Seed \& Brown (1977). Monthly samples of 5 to 10 bivalves were used for histological preparations. Mussels were fixed in $4 \%$ formaldehyde in filtered seawater, rinsed in fresh water after $24 \mathrm{~h}$ and preserved in $70 \%$ ethanol. Following removal of the valves, $10 \mu \mathrm{m}$ thick serial histological sections were taken, stained by hematoxylin and eosin, and examined by light microscopy.

The reproductive cycle of the corals was studied by measurement of oocyte diameter in histological sections (see Shlesinger 1985). Preparation of the sections followed Rinkevich \& Loya (1979).

Early postlarval stages of Lithophaga purpurea were collected from the surface of the corals Montipora erythraea and Cyphastrea chalcidicum, and removed using a fine needle and a pasteur pipette. The young bivalves were examined under a dissecting microscope, and the height of the prodissoconch and the length of the total shell were measured for 25 individuals of each population. The height of the larval shell, defined as the greatest distance from the tip of the umbo to the ventral margin, was used to compare between the bivalve populations.

Shells of postlarvae of Lithophaga purpurea were examined by a Joel JSM-840 SEM. Specimens were dehydrated in a series of alcohols and coated by GoldPalladium.

Fifteen adult bivalves were extracted from 4 to 5 coral colonies of each host coral (either Montipora erythraea or Cyphastrea chalcidicum) by gently breaking the coral. Mussels were immediately stored at $-70^{\circ} \mathrm{C}$. To extract proteins, soft tissues were scraped and homogenized in $15 \%$ sucrose, $0.1 \%$ mercaptoethanol and $0.5 \%$ triton $\mathrm{X}-100$ in saline. Samples were run on vertical polyacrylamide gel ( 7 to $9 \%$ ) in borate buffer $(\mathrm{pH}=8.2)$. Gels were stained for $\alpha$-esterase and aminopeptidase-1 (leucine amino peptidase, LAP) using methods slightly modified from Shaw \& Prasad (1970).

Statistical analyses were carried out according to Sokal \& Rohlf (1969). 


\section{RESULTS}

The 2 Lithophaga purpurea populations show very similar allometric relationships (Fig. 1). The data presented in Fig. 1 represent the allometric relationships between length and height of bivalves extracted from randomly sampled corals. Regression analysis of shell height versus shell length yielded slopes of 0.37 and 0.38 for bivalves extracted from Cyphastrea chalcidicum and Montipora erythraea respectively. These slopes are statistically identical $(p>0.05)$. However, the mean length, height and width of bivalves from

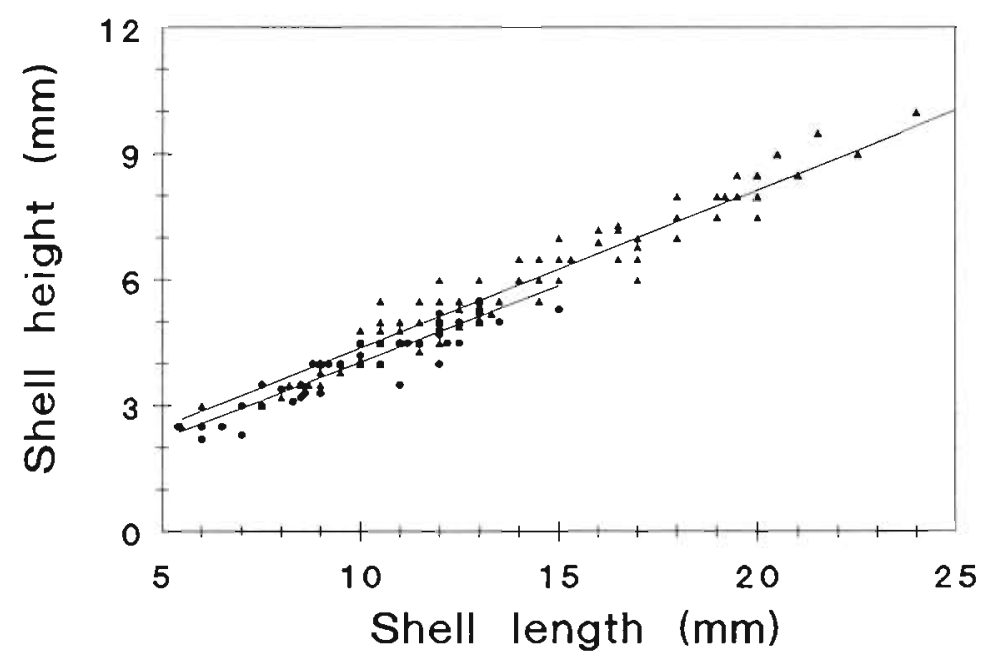

Fig. 1. Lithophaga purpurea. Allometric relationships between shell length and height of specimens extracted from the coral hosts Cyphastrea chalcidicum (•) and Montipora erythraea (^). Curves were fit by linear regression analysis: the top line represents population from $M$. erythraea and the bottom line $C$. chalcidicum

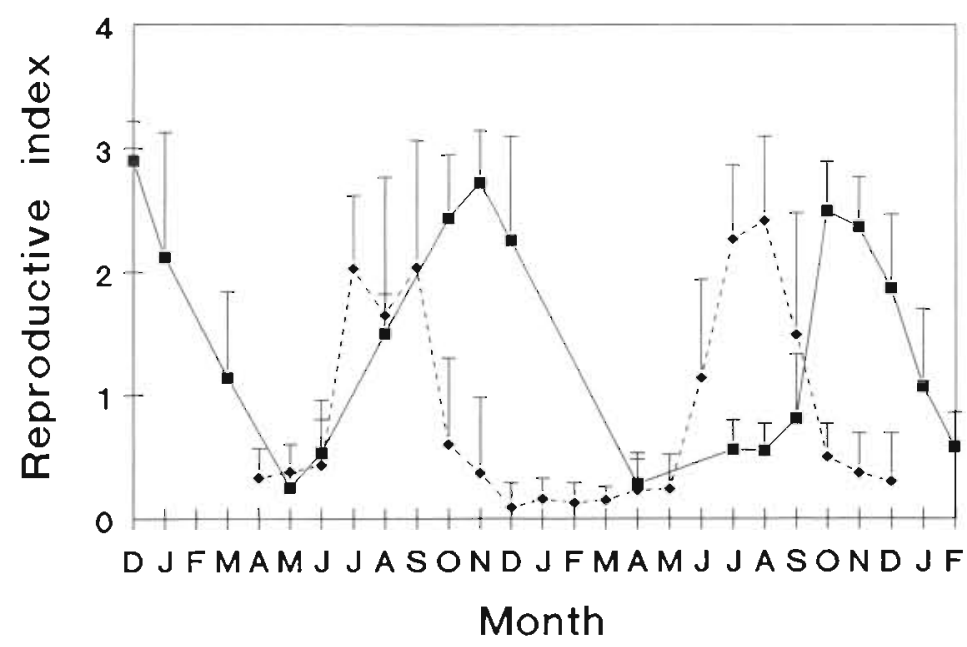

Fig. 2. Lithophaga purpurea. Monthly reproductive indices of 2 populations inhabiting Cyphastrea chalcidicum ( - ) and Montipora erythraea (--.-.)
M. erythraea were significantly greater than these dimensions for bivalves from C. chalcidicum $(\mathrm{p}<0.001$ for all 3 dimensions). Maximal length of bivalves from C. chalcidicum and M. erythraea was 15 and $33.5 \mathrm{~mm}$ respectively.

Two distinct reproductive seasons were revealed for the 2 bivalve populations (Fig. 2). Whereas peak reproduction in Lithophaga purpurea inhabiting Montipora erythraea took place from July to August, peak reproduction in the Cyphastrea chalcidicum bivalve population was found to be during November and December. Both the reproductive index (RI, Fig, 2) and the gonadal index (GI, Fig. 3) reflect this pattern. It is interesting to note the different synchronization patterns between the 2 bivalve populations and their coral hosts. While peak reproduction in $M$. erythraea and its bivalve population coincide, there is no overlap in the reproductive seasons of C. chalcidicum and its inhabiting mussels (Fig. 3). The partial overlap in RI and GI seen in Figs. 2 \& 3 may represent the tail ends of their reproductive seasons.

A significant difference in larval shell height was found between the 2 bivalve populations $(p<0.001)$. The mean prodissoconch height of bivalves from $C$. chalcidicum was $198.0 \pm 8.62 \mu \mathrm{m}$, while larval height of bivalves from Montipora erythraea was $315.2 \pm 16.74 \mu \mathrm{m}$.

SEM observations show distinct shell morphologies of postlarval bivalves inhabiting the 2 coral hosts. The surface of the dissoconch of postlarvae originating from Cyphastrea chalcidicum is characterized by distinct tooth-like structures ('denticles'), as opposed to the smooth shell surface of postlarvae extracted from Montipora erythraea (Fig. 4). The $10 \mu \mathrm{m}$ high denticles are distributed uniformly on the ventral side of the valves, with a fixed distance of $50 \mu \mathrm{m}$ between them

All the bivalves extracted from the coral Montipora erythraea showed a typical LAP pattern of activity consisting of 2 regions, termed 'slow' and 'fast' (Fig. 5B). The 'slow' region contained 3 distinct bands and the 'fast' region consisted of one wide band. In contrast, all bivalves extracted from the coral Cyphastrea chalcidicum showed a pattern of activity composed of a single region, termed 'intermediate'. In most of these bivalves, the 'intermediate' region contained 2 distinct bands, the slower of which may be a part of the 'slow' region typical of bivalves 


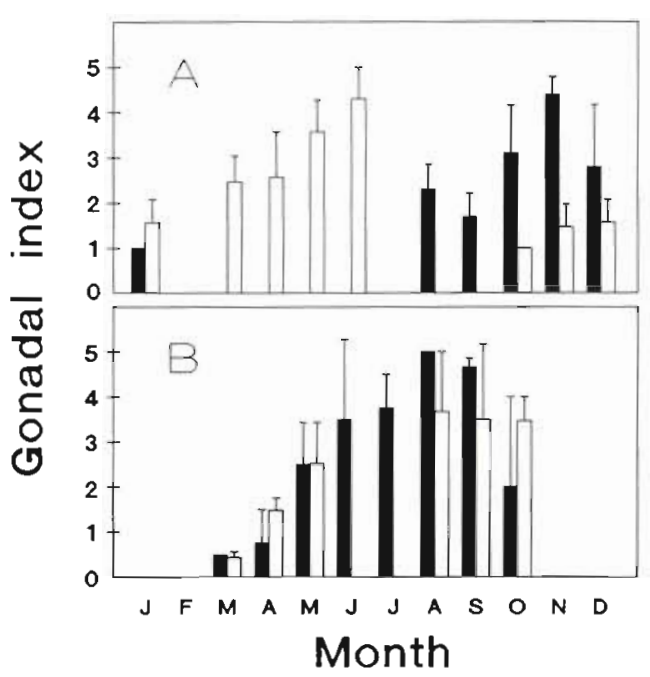

Fig. 3. Lithophaga purpurea. Monthly gonadai indices of bivalves (black bars) and their coral hosts (white bars):

(A) Cyphastrea chalcidicum; (B) Montipora erythraea

extracted from $M$. erythraea. In several bivalves, however, an additional band was slightly visible (Fig. 5B, lanes 3 \& 4), coinciding with the slowest band of $M$. erythraea bivalves. The main band in the 'intermediate' region of activity, shared by all the Lithophaga purpurea extracted from C. chalcidicum, did not appear in any of the bivalves from $M$. erythraea.

Results obtained from gels stained for $\alpha$-esterase also reveal differences between the 2 bivalve populations (Fig. 5A). Both bivalve populations had a common 'intermediate' activity region. Minor banding differences within this region were very difficult to interpret. However, a slow band characterizing bivalves extracted from Montipora erythraea was less distinct in bivalves from Cyphastrea chalcidicum.

\section{DISCUSSION}

Adult Lithophaga purpurea populations inhabiting Cyphastrea chalcidicum and Montipora erythraea are morphologically very similar. Despite significant differences in maximal shell dimensions, which may be caused by different sizes of the host corals, allometric relationships are almost identical.
The observed marked differences in reproductive periods suggest reproductive isolation between the 2 populations. The bivalves inhabiting Montipora erythraea reproduce during late summer, while those from Cyphastrea chalcidicum reproduce during early winter (Figs. 2 \& 3), with very little overlap between the 2 reproductive seasons. Gametes are either at a premature stage (Lithophaga purpurea from C. chalcidicum) or degenerating ( $L$. purpurea from $M$. erythraea) during the period of reproductive overlap.

Careful examination of various physical parameters of postlarvae of the 2 Lithophaga purpurea populations revealed marked differences. The mean height of the prodissoconch of postlarvae which settled on Montipora erythraea is considerably larger than that of postlarvae from Cyphastrea chalcidicum. Furthermore, the distinct dentition found on the dissoconch of the C. chalcidicum inhabiting bivalves does not exist on the shells of the $M$. erythraea bivalve population. The differences in surface texture between the bivalve populations may imply different mechanisms of boring (i.e. mechanical vs chemical boring; see Morton \& Scott 1980, Fang \& Shenn 1988, Lazar \& Loya 1991 for more details about boring mechanisms). These findings further support the suggestion that the 2 populations are indeed different species. Furthermore, activity patterns obtained for both of the assayed enzymes, LAP and $\alpha$-esterase, support the supposition that the 2 populations of $L$. purpurea are genetically distinct.

Populations of the same species, living under different environmental conditions, may demonstrate differences in various biological features. Differences in reproductive timing between bivalve populations may be affected by physical environmental factors, such as temperature (see Brown 1984). However, we do not expect these factors to play a major role in the case of the studied Lithopaga purpurea populations, since both coral hosts share the same macroenvironment in the reefs of the Gulf of Eilat. Shafir \& Loya (1983) described Lithopaga lessepsiana feeding on the mucus of its host coral Stylophora pistillata. There is a possibility that $L$. purpurea also uses such a food source. It may be argued that possible differences in energetic or nutritional value between the mucus of the coral hosts may cause the differences in the reproductive cycle of the $2 \mathrm{~L}$. purpurea populations (see Newell et al. 1982). However, in addition to the differ-

Fig. 4. Lithophaga purpurea. Scanning electron micrographs (SEM) of postlarval shells. (A) Valves of $L$. purpurea taken from the coral Cyphastrea chalcidicum. Scale bar $=100 \mu \mathrm{m}$. (B) Valves of $L$. purpurea taken from the coral Montipora erythraea. Note the lack of denticles. Scale bar $=100 \mu \mathrm{m}$. (C) Another specimen of $L$. purpurea from $C$. chalcidicum, photographed at a different orientation, to show the uniform distribution of the denticles. Scale bar $=100 \mu \mathrm{m}$. (D) Closeup of denticles. Scale bar $=50 \mu \mathrm{m}$ 

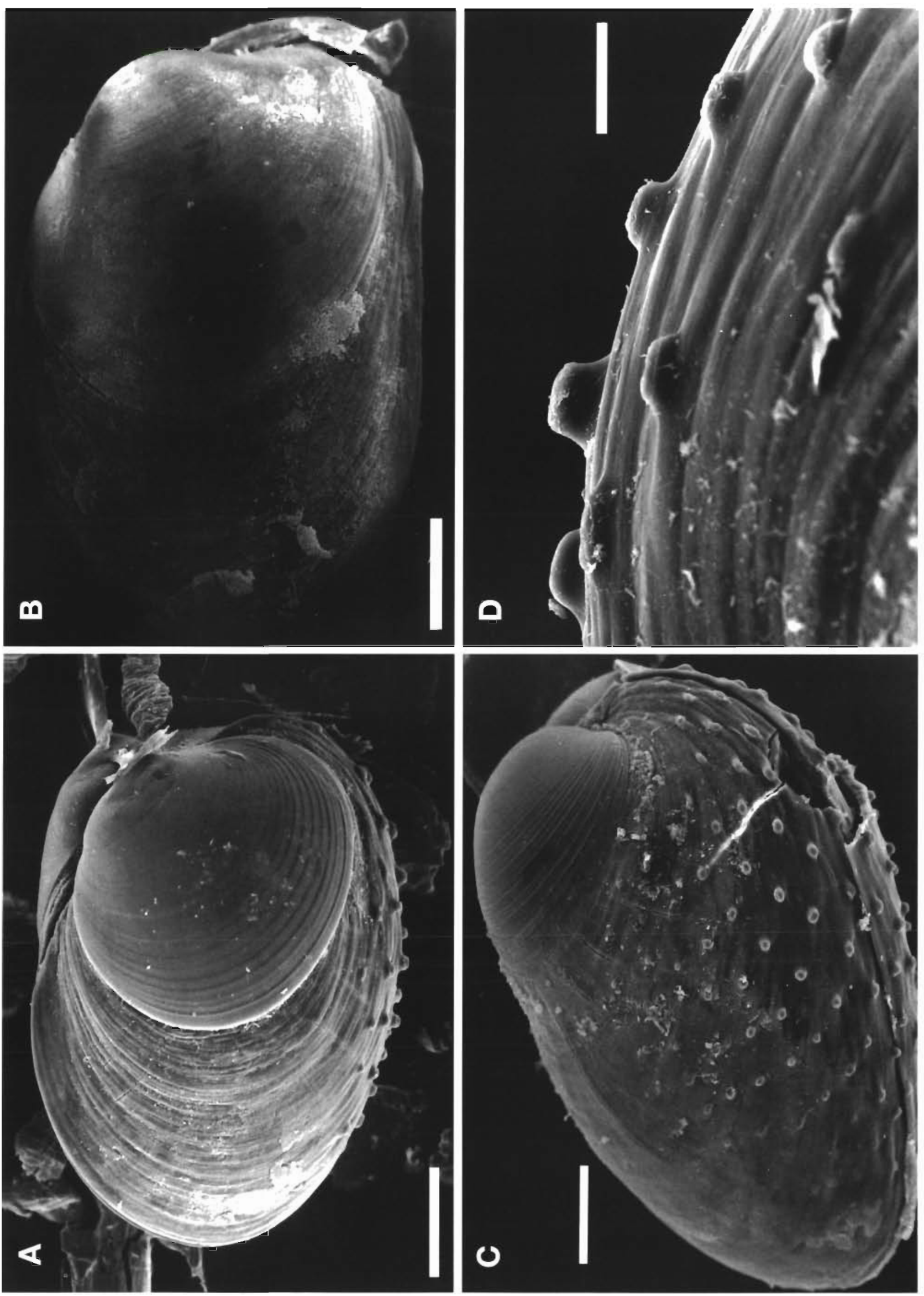


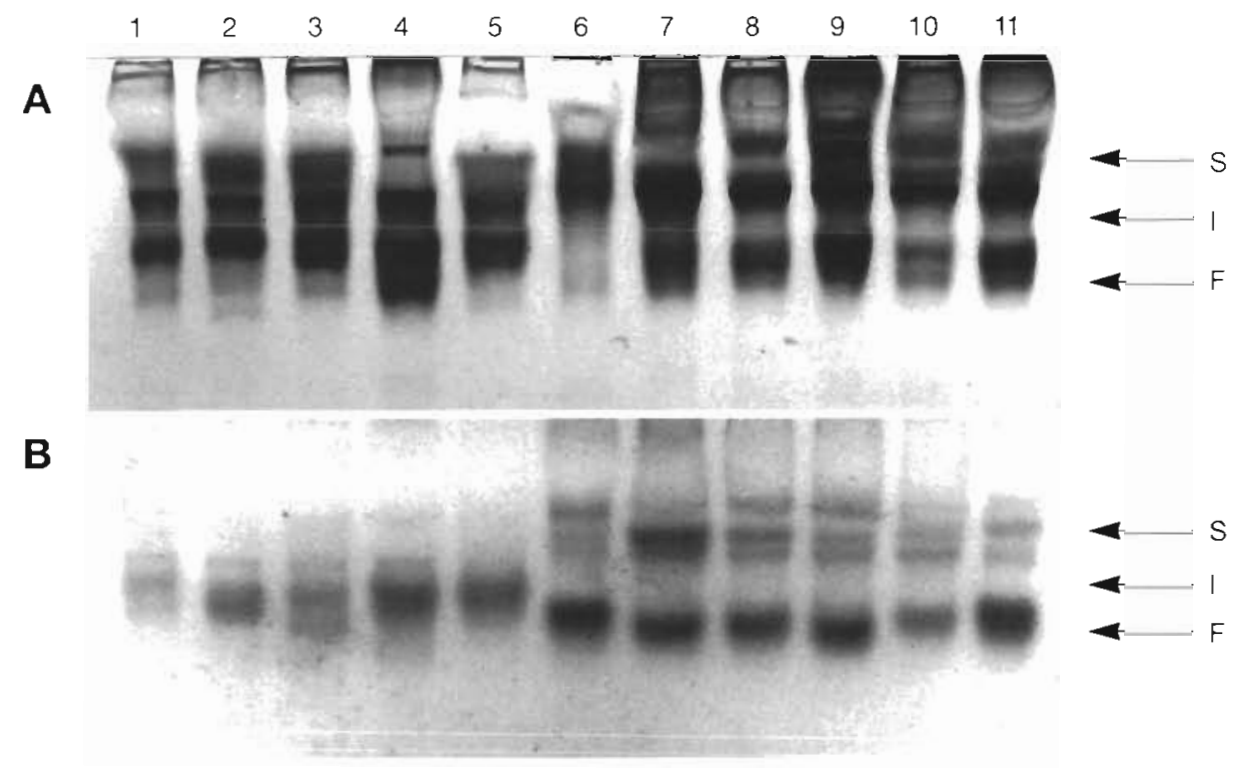

Fig. 5. Gel electrophoresis of proteins extracted from Lithophaga purpurea bivalves. (A) Gel stained for $\alpha$-esterase activity. Lanes 1 to 6: bivalves from C. chalcidicum; lanes 7 to 11 . bivalves from $M$. erythraea. (B) Gel stained for LAP activity. Lanes 1 to 5 : bivalves from $C$. chalcidicum; lanes 6 to 11: bivalves from $M$. erythraea. S: 'slow' region; I: 'intermediate' region; $F$ : 'fast' region

ences in the reproductive seasons of these 2 populations, the differences revealed by both SEM and enzymatic studies suggest that they should, indeed, be considered 2 distinct species.

Loya (1981) reported that Lithophaga lessepsiana reproduces simultaneously with its coral host, Stylophora pistillata. At the onset of the coral's reproduction, its calcification rate decreases, hence its growth rate is reduced. Under these conditions there is a smaller chance of the bivalve's aperture being covered by the coral's skeleton. Consequently, the bivalve may direct more energy towards reproduction, rather than to growth. Thus, one might expect shifts in the reproductive timing of $L$. purpurea, according to the reproductive period of the coral host. The presented difference in reproductive season between the populations of $L$. purpurea is evidently not a result of the differences in reproductive seasons of the coral hosts. While the reproductive peak of the $M$. erythraea inhabiting $L$. purpurea population coincides with that of the coral host, there is a time shift in the reproductive peaks between Cyphastrea chalcidicum and its bivalve tenants (Fig. 3 ). In this case, therefore, it is not probable that the difference in reproductive peaks of the bivalve populations is affected by the difference in the coral host's reproductive season.

One of the fundamental components of the 'biological species' concept is the existence of gene flow and interbreeding within a group of organisms (Mayr 1963). New species may evolve when 2 or more groups of organisms are kept from genetically mixing (Templeton 1989). Reproductive isolation may be achieved by physical barriers, or by lack of synchrony in reproductive timing Despite the slight overlap in RI and GI (Figs. 2 \& 3), the vast majority of each bivalve population reproduces at distinct times. We therefore suggest that the 2 populations of Lithophaga purpurea, which clearly experience reproductive isolation, are undergoing speciation. Tauber \& Tauber (1989) define a species as a group of populations whose evolutionary pathway is separate from that of other groups. This separation may be achieved, as in the case of $L$. purpurea, through reproductive isolation.

Morton (1983) considers Lithophaga purpurea to be a 'wide spectrum' borer (inhabiting several species of corals). He also pointed out the 'need for a very careful recording of well-defined species of borers and host corals, in order to determine accurately the extent to which particular species of borers associate with different species of corals'. If the 2 different $L$. purpurea populations are indeed distinct species as we propose, then they should be considered 'narrow spectrum' borers, each boring in 1 coral species. Chemical factors in the coral host tissue may promote the observed coral-bivalve specificity, by inducing settlement and metamorphosis of specific larvae, as in the case of L. lessepsiana (Mokady et al. 1991).

Finally, the results presented in this study should prompt a thorough reevaluation of the systematic complex of bivalves of the genus Lithophaga. Efforts in the direction of using mtDNA sequences to compare closely related populations of Lithophaga are currently being undertaken in our laboratory. If such an investigation yields similar results for other Lithophaga species (i.e. populations inhabiting different corals are genetically distinct), it may shed a new light on reefal cryptofauna in general, and on the relationships between cryptobionts and their living coral substrates in particular. 
Acknowledgements. We thank Dr K. Kleemann for identifying specimens of Lithophaga bivalves from the Red Sea and Dr R. Ben-Hillel for her help in histological preparations. Thanks are also due to Y. Langzam of the EM laboratory at Bar llan University, and to the H. Steinitz Marine Biology Laboratory, at Eilat. This research was supported by the USAIsrael Binational Science Foundation (BSF), Jerusalem, Israel.

\section{LITERATURE CITED}

Brickner, I. (1985). Reproductive and settlement strategy of the boring bivalve Lithophaga purpurea in living corals. M.Sc. thesis, Tel Aviv University, Tel Aviv (Hebrew, English abstract)

Brown, R. A. (1984). Geographical variations in the reproduction of the horse mussel Modiolus (Mollusca, Bivalvia) J. mar. biol. Ass. U.K. 64: 751-770

Culliney, J. L. (1971). Laboratory rearing of larvae of the mahogany date mussel Lithophaga bisulcata. Bull. mar. Sci. 21: 591-602

Fang, L., Shenn, P. (1988). A living mechanical file: the burrowing mechanism of the coral boring bivalve Lithophaga nigra. Mar. Biol. 97: 349-354

Gohar, H. A. F., Soliman, G. N. (1963). On three mytilid species boring in living corals. Publs. mar. biol. Stn Ghardaqa 12: $65-98$

Goodsell J. G., Fuller, S. C., Eversole, A. G., Castagna, M., Lutz, R. (1992). Larval and early postlarval shell morphology of several venerid clams. J. mar. biol. Ass. U.K 72: $231-255$

Kleemann, K. H. (1980). Boring bivalves and their host corals from the Great Barrier Reef. J. mollusc. Stud. 46: 13-54

Koehn, R. K., Mitton, J. B. (1972). Population genetics of marine pelecypods. I. Ecological heterogeneity and evolutionary strategy at an enzyme locus. Am. Nat. 106: 47-56

Lazar, B., Loya, Y. (1991). Bioerosion of coral reefs - a chemical approach. Limnol. Oceanogr. 36: 377-383

Loya, Y. (1981). Life history strategies of the boring bivalve Lithophaga lessepsiana in the coral Stylophora pistillata. Proc. 4th int. Symp. coral Reef 2: 756

MacGeachy, J. K., Stearn, C. W. (1976). Boring by macroorganisms in the coral Montastrea annularis on Barbados reefs. Int. Rev ges. Hydrobiol. 61: 715-745

Mayr, E. (1963). Animal species and evolution. Harvard University Press, Cambridge

McLaughlin, P. A., Taylor, G. T., Tracey, M. L. (1982) Systematic methods in research. In: Abele, L. G. (ed.) The biology of Crustacea, Vol. 1. Academic Press, New York, p. 29-63

Mokady, O., Arazi, G., Bonar, D. B., Loya, Y. (1991). Coral host specificity in settlement and metamorphosis of the date mussel Lithophaga lessepsiana (Vaillant, 1865). J. exp. mar. Biol. Ecol. 146; 205-216

Mokady, O., Arazi, G., Bonar, D. B., Loya, Y. (1992). Settlement and metamorphosis specificity of Lithophaga simplex Iredale, 1939 (Bivalvia: Mytilidae) on Red Sea corals. J. exp. mar. Biol. Ecol. 162: 243-251
Mokady, O., Bonar, D. B., Arazi, G., Loya, Y. (1993). Spawning and development of three coral associated Lithophaga species in the Red Sea. Mar. Biol. 115: 245-252

Morrow, C. C., Thorpe, J. P., Picton, B. E. (1992). Genetic divergence and cryptic speciation in two morphs of the common subtidal nudibranch Doto coronata (Opisthobranchia: Dendronotacea: Dotoidae) from the northern Irish Sea. Mar. Ecol. Prog. Ser. 84: 53-61

Morton, B. (1983). Coral-associated bivalves of the IndoPacific. In: Russel-Hunter, W. D. (ed.) The Mollusca, Vol. 6. Academic Press, Orlando, p. 139-224

Morton, B., Scott, P. J. B. (1980). Morphological and functional specializations of the shell, musculature and pallial glands in the Lithophaginae (Mollusca: Bivalvia). J. Zool. Lond. 192: 179-203

Newell, R. I. E., Hilbish, T. J., Koehn, R. K., Newell, C. J. (1982). Temporal variation in the reproductive cycle of Mytilus edulis L. (Bivalvia, Mytilidae) from localities on the east coast of the United States. Biol. Bull. 162: 299-310

Rinkevich, B., Loya, Y. (1979). The reproduction of the Red Sea coral Stylophora pistillata. I. Gonads and planulae. Mar. Ecol. Prog. Ser. 1: 133-144

Shlesinger, Y. (1985). Reproduction and juvenile growth in stony corals. Ph.D. thesis, Tel Aviv University, Tel Aviv (Hebrew, English abstract)

Scott, P. J. B. (1988). Initial settlement behaviour and survivorship of Lithophaga bisulcata (Mytilidae: Lithophaginae). J. mollusc. Stud 54: 97-108

Seed, R. (1969). The ecology of Mytilus edulis L. (Lamellibranchiata) on exposed rocky shores. I. Breeding and settlement. Oecologia 3: 277-316

Seed, R., Brown, R. A. (1977). A comparison of the reproductive cycles of Modiolus modiolus (L.) Cerastoderma (=Cardium) edule (L.) and Mytilus edulis (L.) (Mollusca: Bivalvia) in Strangford Lough, Northern Ireland. Oecologia 30: $173-188$

Shafir, A., Loya, Y (1983). Consumption and assimilation of coral mucus by the burrowing mussel Lithophaga lessepsiana. Bull. Inst. Oceanogr. Fish. 9: 135-140

Shaw, C. R., Prasad, R. (1970). Starch gel electrophoresis of enzymes: a compilation of recipes. Biochem. Genet. 4: $297-320$

Sokal, R. R., Rohlf, F. J. (1969). Biometry. W. H. Freeman and Company, San Francisco

Tauber, C. A, Tauber, M. J. (1989). Sympatric speciation in insects: perception and perspective. In: Otte, D., Endler J. A. (eds.) Speciation and its consequences. Sinauer Associates, Inc., Sunderland, MA, p. 307-344

Templeton, A. R. (1989). The meaning of species and speciation: a genetic perspective. In: Otte, D., Endler, J. A. (eds.) Speciation and its consequences. Sinauer Associates, Inc., Sunderland, MA, p. 3-27

Wilson, B. R. (1979). A revision of Queensland lithophagine mussels (Bivalvia, Mytilidae, Lithophaginae). Rec. Aust. Mus. 32: 435-489

Winter, E. (1985). The life history strategy of the bivalve Lithophaga purpurea boring in the coral Cyphastrea chalcidicum. M.Sc. thesis, Tel Aviv University, Tel Aviv

Manuscript first received: March 23, 1993

Revised version accepted: July 21, 1993

This article was submitted to the editor 